\title{
Doktorlar için bir klinik zorluk: Abdominal tüberküloz 24 olgunun derlemesi
}

\author{
Clinical challenge for physicians - abdominal tuberculosis: review of 24 cases
}

Meltem ERGÜN, Bilge TUNÇ, Aysel ÜLKER, Nurgül ŞAŞMAZ

Department of Gastroenterology, Türkiye Yüksek Ihtisas Education and Research Hospital, Ankara

\begin{abstract}
Amaç: Abdominal tüberküloz halen gelișmekte olan ülkelerde immun yetmezliği olmayan bireylerde görülebilen bir hastalıktır. Kesin tanı öncelikle bu hastalıktan süphelenilerek ve farklı tanı metotlarını bir arada kullanarak mümkündür ve uzun zaman alabilir. Gereç ve Yöntem: Ocak 2000 ile Aralık 2011 tarihleri arasında kliniğimizde abdominal tüberküloz tanısı konulan 24 hastanın kaytlarn retrospektif olarak analiz edildi. Demografik özellikler, laboratuar kayıtlarn, radyolojik, endoskopik ve cerrahi bulgular değerlendirildi. Takipler hastalara randevu verilerek veya telefonla yapılan görüsmelerle sağlandı. Bulgular: Toplam 24 hasta çalışmaya dahil edildi (10 bayan, ortalama yaş: 40, dağılım: 21-68). Hastaların en sık klinik semptomu ateş (20 \%83), karın ağrisı (19,\%79), iştahsızlık (17, \% 71), kilo kaybı (16,\%66), gece terlemesi (12,\%50), ishal (10,\%42), asit (8, \%33) olarak saptand. Subakut/akut intestinal obstrüksiyon olgularnn 5'inde (\%21) saptandl. Hastalarin 4'ünde (\%16) geçirilmiş pulmoner tüberküloz hikâyesi, 5 'inde (\%21) ailede tüberküloz hikâyesi mevcuttu. Hastaların 12'sinde (\%50) intestinal tutulum saptanırken, 8'inde (\%30) peritoneal ve 4'ünde nodal tutulum saptandı. Intestinal tutulum gösteren hastaların 9'unda (\%75) ileoçekal bölgede lezyon saptandı. Abdominal tüberküloz tanısı 8 (33\%) hastada endoskopik/ kolonoskopik biopsilerin histo-patolojik incelemesiyle, 5 (21\%) hastada abdominal ultrason/tomografi rehberliğinde yapılan biyopsilerle, 7 (29\%) hastada laparoskopik/cerrahi girișimle, 2 (8\%) hastada da asit incelemeleri ile kondu. Mikrobiolojik incelemelerde pozitiflik sadece 4 (17\%) hastada saptandi. Sonuç: Abdominal tüberküloz spesifik olmayan semptomatolojisi ile karmaşık bir hastalıktır. Tanısını koymak için öncelikle şüphelenmek ve bir çok tanı metotlarnı bir arada kullanmak gerekir.
\end{abstract}

Anahtar kelimeler: Gastrointestinal tüberküloz, abdominal tüberküloz, intestinal tüberküloz

\section{GİRISS}

Gelişmiş ülkelerde tüberküloz (TBC) insidansı, insan immun yetmezlik virusu (HIV-Human immun deficiency virus) infeksiyonu, kemoterapi gibi immun sistem supresyonuna yol açan durumlardan ötürü artmaktadır. Gelişmekte olan ülkelerde ise yetersiz sanitasyon ve kötü yaşam şartları TB infeksiyonunun temel sebebi olarak ortaya çıkmaktadır (1). Dünya Sağlık Örgütünün 2011 yılı raporunda dünya nüfusunun yaklaşık 1/3'ünün TBC basili ile infekte olduğu ve basilin infeksiyoz nedenler içinde en sık mortaliteye neden olan 2. patojen olduğu bildirilmiştir. HIV virusu taşıyan hastalarınsa neredeyse \%50'sinin TBC basili ile infekte olduğu bilinmektedir $(2,3)$. Tüberkülozun halen en sik prezentasyonu pulmoner TBC olmakla birlikte, vakaların yaklaşık \%10-20'sinde ekstrapulmoner tutulum da saptanabilmektedir (4). Tüm dünyada genel olarak bakıldığında pulmoner TBC insidansı-
Background and Aims: Abdominal tuberculosis is still seen in immunocompetent adults in developing countries. The accurate diagnosis of abdominal tuberculosis requires a high index of suspicion and combination of diagnostic modalities in clinic practice and is time-consuming. Materials and Methods: The records of 24 patients (10 females, mean age: 40 years, range: 21 68 years) diagnosed with abdominal tuberculosis between January 2000 and December 2011 were analyzed retrospectively. Patients' characteristics, laboratory investigations, and radiological, endoscopic and surgical findings were evaluated. Follow-up information was obtained by telephone contact and scheduled visits. Results: 24 patients were enrolled in the study. The most frequent symptoms were abdominal pain $(n=19,79 \%)$, fever $(n=20,83 \%)$, ascites $(n=8,33 \%)$, diarrhea $(n=10,42 \%)$, and weight loss $(n=16,66 \%)$. Subacute/acute intestinal obstruction was found in 5 cases. Past history of treatment for tuberculosis and family history of tuberculosis were present in 4 (16\%) and $5(21 \%)$ patients, respectively. The basis of diagnosis of abdominal tuberculosis were histopathology obtained by endoscopic/colonoscopic biopsies in 8 (33\%), ultrasound/computed tomography-guided biopsies in 5 (21\%), laparoscopic/surgical interventions in 7 (29\%), and ascites examinations in $2(8 \%)$ patients. Microbiological tests were positive in only 4 (17\%) patients. The predominant site of involvement by abdominal tuberculosis was intestinal in 12 (50\%), peritoneal in 8 (33\%), and solid viscera/nodal in 4 (16\%) cases. Conclusions: Abdominal tuberculosis is a complex disease with non-specific symptomatology. Combination of a high index of clinical suspicion and use of multiple adjuvant diagnostic tools is required to make the correct diagnosis.

Key words: Gastrointestinal tuberculosis, abdominal tuberculosis, intestinal tuberculosis

nın azalmakta olduğu, ancak abdominal TBC insidansının giderek arttığı görülmektedir $(3,4)$. Abdominal TBC enterik, peritoneal, nodal ve solid organ tutulumu sseklinde seyredebilmektedir. İntestinal tutulum hiperplastik, ülsere ve kombine şekilde görülebilmektedir (5). Klinik prezentasyonu kronik diyare, kilo kaybı, ateş ve asit şeklinde olabilmekte ve bu bulgularla pek çok hastalıkla karışabilmektedir. En sık karıştığı hastalık Crohn hastalığı olmakla birlikte maligniteler, periapendiküler abse, yersinia, amip infeksiyonları da ayırıcı tanıda önem taşımaktadır (6). Basili göstermeye yönelik tanısal metodların farklı sensitivite ve spesifiteleri klinisyenleri bu metodları kombine etmeye, biyopsi tekrarlarına ve bazı olgularda laparoskopik biyopsiye yöneltmektedir. Nadir olgularda ise yüksek klinik şüphe ile basil gösterilemese de tedavi başlanabilmektedir. 
Çalışmamızın amacı Ocak 2000 ile Aralık 2011 tarihleri arasında kliniğimizde tanı konmuş abdominal TBC olgularının prezentasyonu, tanı metodları ve tedavi sonuçlarını değerlendirmektir.

\section{GEREÇ VE YÖNTEM}

Ocak 2000 ile Aralık 2011 tarihleri arasında Türkiye Yüksek Ihtisas Hastanesi Gastroenteroloji Kliniğinde abdominal TBC tanısı alan 18 yaş üstü hastalar çalışmaya alındı. Hastaların klinik bulguları laboratuvar incelemeleri ve tedavileri takip dosyalarından retrospektif olarak tarandı. Poliklinik sonuçları incelendi, takibinde eksiklik olan hastalara da telefon ile veya kontrol vizitine davet edilerek ulaşıldı.

Hastaların demografik özellikleri, özgeçmişlerinde pulmoner TBC olup olmaması, ailede TBC hikâyesi özellikle sorgulandı. PPD testi, akciğer grafisi/bilgisayarlı tomografi (BT) bilgileri değerlendirildi. Abdominal TBC tanısına ulaşmak için kullanılan tetkik metodları asit incelemesi sonuçları, endoskopi, kolonoskopi, baryumlu ince barsak pasaj grafileri, abdominal BT sonuçları kaydedildi.

Abdominal TBC tanısı

a) Laboratuvar incelemelerinde PCR (polymerase chain reaction) ile basilin saptanması,

b) Patolojik değerlendirmede granülom görülmesi ve basilin saptanmasi,

c) Kültürde basilin üretilmesi,

d) Patolojik değerlendirme ve radyolojik bulguların desteklediği olgularda basil gösterilememesi durumunda yüksek klinik şüphe varsa tedavi verilerek hastanın tedaviye olumlu yanıt vermesi halinde kondu.

Abdominal TBC olguları ayrıca

a) Intestinal $\mathrm{TBC}$

b) Peritoneal TBC

c) Nodal/solid organ TBC olarak sinıflandi.

İstatistik Analiz

Sonuçlar ortalamaıstandart sapma, veri aralığı ve yüzde olarak ifade edildi. Devaml değişkenler için "Mann-Whitney U testi", kategorik data için ise "ki-kare testi" kullanıldı. Tüm veriler çift yönlü olarak değerlendirildi ve p<0.05 düzeyi anlamlı olarak kabul edildi. Verilerin değerlendirilmesinde "Statistical Package for the Social Sciences version (SPSS) 12.0" kullanıldı.

\section{BULGULAR}

\section{Olguların Demografik, Klinik Özellikleri}

Ocak 2000 ile Aralık 2011 tarihleri arasında Türkiye Yüksek
Ihtisas Hastanesi Gastroenteroloji Kliniğinde abdominal TBC tanısı alan 24 hastanın (10 bayan), yaş ortalaması 40 (21-68) idi. Hastaların en sık klinik semptomu ateş olup (20 hastada, \%83), 19 hastada karın ağrısı (\%79), 17 hastada iştahsızlık (\% 71), 16 hastada kilo kaybı (\%66), 12 hastada gece terlemesi (\%50), 10 hastada ishal $(10, \% 42)$ ve 8 hastada asit (\%33) saptandı. Subakut/akut intestinal obstrüksiyon olguların 5'inde (\%21) görüldü. Hastaların 4'ünde (\%16) geçirilmiş pulmoner TBC hikayesi, 5'inde (\%21) ailede TBC hikayesi mevcuttu. Olguların 2'sinde (\%8) diabetes mellitus ve l'inde karaciğer sirozu (\%4) eşlik etmekteydi.

\section{Tanı Yöntemleri ve Bulgular}

Hastalarin 12'sinde (\%50) intestinal tutulum saptanirken, 8'inde (\%33) peritoneal ve 4'ünde nodal tutulum saptand..

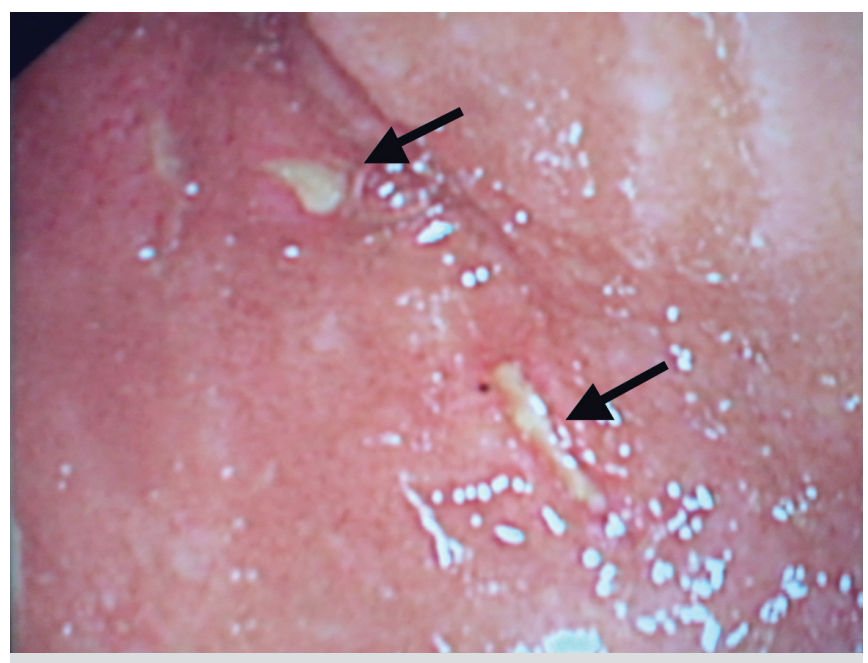

Resim 1. lleum içinde ülserler (Siyah ok).

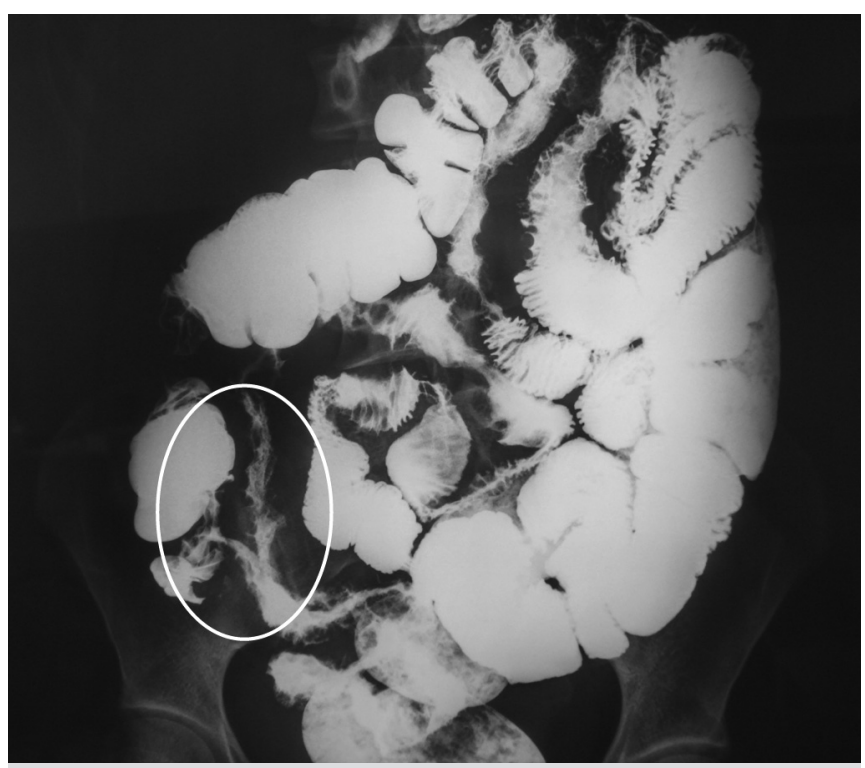

Resim 2. Baryumlu ince barsak incelemesinde ileoçekal bölgede tutulum 
Intestinal tutulum gösteren hastaların 9'unda (\%75) ileoçekal bölgede lezyon saptandı. Ileoçekal valvde deformite ve ülser en sık kolonoskopik bulgu olup ( $\mathrm{n}=9$ ), kolonik ülserasyon ve yarım daire şeklinde ülserler 8 hastada ve ileum içinde ülserler de 4 hastada tespit edilmiștir (Resim 1,2). Nodüler, hipertrofik lezyon ise 2 olguda görülmüştür.

Intestinal tutulum gösteren hastaların 8'inde (\%66) ilk kolonoskopik incelemede alınan örneklemede kazeifiye/nonkazeifiye granülom saptanırken basil sadece 2'sinde gösterilmiştir (Resim 3,4). Kültür olguların l'inde pozitif saptanmıştır. Örneklemin mikrobiyolojik incelemesinde 4 olguda TBC PCR incelemesi pozitif saptanırken, 4 hastada kolonoskopi işlemi tekrarına ve tekrar biyopsi alınmasına gerek duyulmuștur. Olguların birinde patolojik değerlendirmede basil saptanırken, bir olguda da PCR pozitifliği elde edilmiştir. 2 hastada laparoskopik biyopsi ile tanı konurken, ileus tablosu olan 1 hastaya laparotomi ve ileoçekal rezeksiyon yapılmıştır.

Peritoneal tutulum gösteren hastaların tamamında serum asit albümin gradiyenti 1, l'in altında bulunmuştur. Asit adenozin deaminaz (ADA) incelemesi mevcut olan 6 hastada ortalama 32,3 \pm 14 (18-56) U/L olarak saptanmıştır. Hastaların 5'inde BT'de omental kalınlaşma saptanmıştır. Hastaların 2'sinde omental biyopsi değerlendirmesinde basil saptanırken, 2 hastada tanısal amaçlı laparoskopik biyopsi yapılmıştır. 1 hastada patolojik değerlendirmede kazeifikasyon nekrozu saptanmış, 1 hastada nonkazeifiye granülom gösterilmiş, iki hastaya da kuvvetli klinik şüphe nedeniyle anti TBC tedavi başlanmıştir.

Nodal TBC saptanan 4 olgudan 2 olguya görüntüleme eşliğinde biyopsi ile ve 2 olguya da laparoskopik biyopsi ile tanı konmuştur.

Hastaların tamamına dörtlü anti TBC tedavi başlanmıştır. Dört hastada karaciğer enzimlerinde 5 kattan daha fazla yükselme saptandığından tedavi kesilmiş, takipte karaciğer fonksiyonları normale dönen hastalara tekrar tedavi başlanmıştır. Bir hastada yeniden karaciğer enzimlerinde yükselme tespit edildiğinden tedaviye hepatotoksik olmayan ilaçlarla (streptomisin, etambutol ve kinolon ile) devam edilebilmiştir. Tüm hastalar 18 ay tedavi almıştır. Kontrol endoskopik işlem ve görüntüleme yöntemi takip esnasında birinci yılda yapılması planlanmıştır. Kontrol endoskopik işlem sonuçlarına ulaşılabilen 9 hastanın 7`sinde lezyonlar tamamen kaybolmuş, 2 hastada lezyon olan alanlarda skar dokusu izlenmiștir. Peritoneal TBC saptanan olguların üçünde görüntüleme sonuçlar1na ulaşılabilmiş ve asitin kaybolduğu tespit edilmiştir.

2 hasta seyir sırasında oluşan komplikasyon nedeniyle (ileusileal rezeksiyon- postop komplikasyon) kaybedilmiştir.

\section{TARTISSMA}

Abdominal TBC tüm dünyada sıklığı giderek artan bir ekstra- pulmoner TBC tipidir. TBC gelişmiş ülkelerde HIV gibi immun sistemi suprese eden virus infeksiyonlarna veya sistemik kemoterapiye bağlı olarak görülmekte ise de, ülkemiz gibi gelişmekte olan ülkelerde immun sistemi normal kişilerde de yetersiz hijyen, kalabalık aile ortamı gibi sebeplerle halen görülmeye devam etmektedir $(1,2)$. Bizim çalışmamızda erkek hastalarda daha sık abdominal TBC tespit edilmiştir, bazı çalışmalarda kadın predominansı gözlenmekte ve bu da daha çok tedavi edilmemiş salpenjitin intraabdominal yayılımına bağlanmaktadır, bazı çalışmalarda ise bizimkine benzer şekilde erkek predominansı gözlenmektedir (7-9).

Abdominal TBC'nin klinik bulguları karın ağrısı, ateş, kilo kaybı, iştahsızlık, ishal veya kabızlık, asit gelişimi, daha nadir

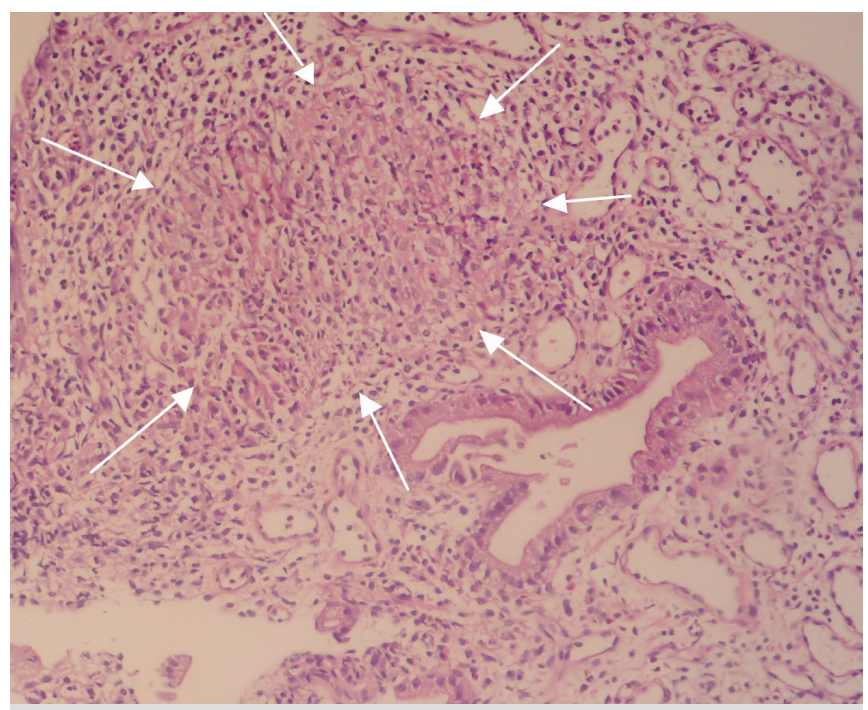

Resim 3. Intestinal tüberkülozlu bir hastada patolojik değerlendirmede saptanan non-kazeifiye granülom (Sınırları oklarla belirlenmiștir)

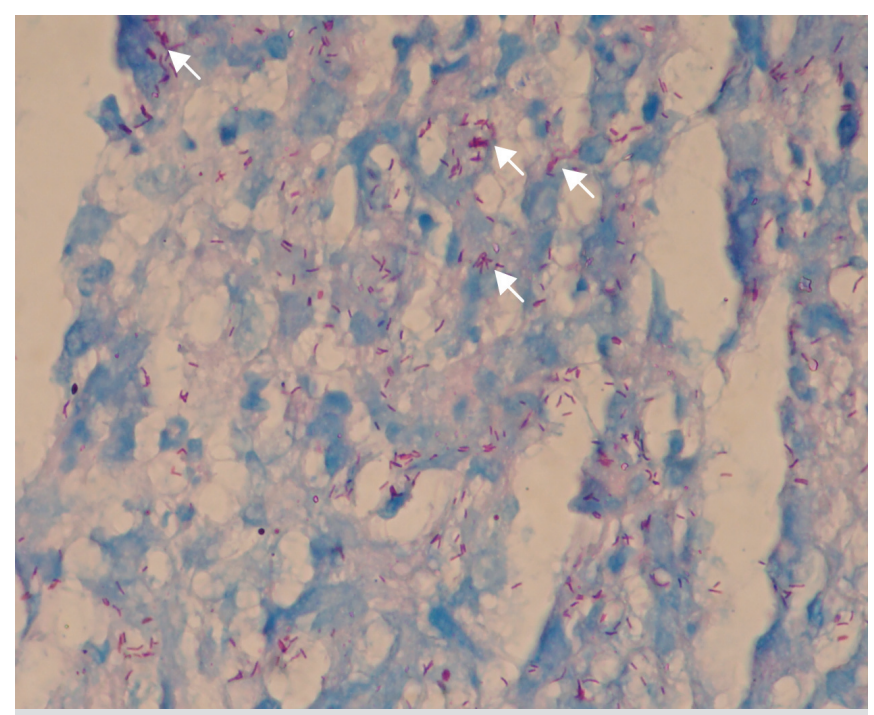

Resim 4. Intestinal tüberküloz tanısı almış bir hastada Ehrlich-Ziehl-Neelsen boyama ile gösterilen basiller (Oklarla gösterilen pembe renkte boyanan çok sayıda aside dirençli M. tüberkülosis basilleri). 
olgularda da hepatomegali, splenomegali şeklinde olmaktadır (9-10). Bizim hastalarımızda da ateş, karın ağrısı, iştahsızlık, kilo kaybı, gece terlemesi, ishal, asit en sık görülen klinik semptomlar olarak saptandı. Subakut/akut intestinal obstrüksiyon olguların 5'inde mevcuttu. Geçirilmiş pulmoner TBC hikâyesi ve aile bireylerinde TBC öyküsü, belirtilen semptomları olan hastalarda, abdominal TBC olasılığını kuvvetlendirmekte olup, bizim hastalarımızın da üçte birinden fazlasında geçirilmiş TBC veya aile öyküsü mevcuttu.

Abdominal TBC tanısını görüntüleme yöntemleri ile düşündüren bulgular: baryum incelemesinde özellikle ileoçekal valv bölgesine uyan bölgesinde daralma, BT'de asit, omental kalınlaşma, abdominal lenfadenopatiler ve barsak duvarında kalınlaşmadır. Kolonoskopik bulgular ise deforme çekum, deforme ileoçekal valv, mukozal ülserasyonlar, nodüller ve striktürlerdir.

Abdominal TBC'nin tanısı öncelikle klinik şüpheye ve görüntüleme yöntemlerine dayanmakta ancak basilin gösterilmesi veya üretilmesi oldukça güçlük arzetmektedir (8-10). Şüphelenilen hastada aile öyküsü ve özgeçmişin TBC yönünden ayrıntılı sorgulanmasının ardından akciğer grafisi ve/veya tomografisi, balgam kültürü, PPD testi yapılması önemlidir (1112). Bunlarda pozitiflik saptanması tanıy destekleyebilir ancak negatif olması hastalığı ekarte ettirmez. Intestinal tutulumu olan TBC olgularında endoskopik ve/veya kolonoskopik olarak inceleme yapılması, saptanan lezyonlardan çok sayıda biyopsi alınması önemlidir. Patolojik incelemenin TBC yönünden daha ayrıntılı olarak yapılması, basili göstermeye yönelik boyaların yapılması önem taşımaktadır. Ayrıca alınan biyopsi örneklerinde PCR incelemesi ve kültür de yapilmasi önerilmektedir. Illk incelemeler basili göstermede yetersiz kalırsa mutlaka endoskopik incelemeler tekrarlanarak yeni örneklemeler yapılmalıdır. Peritoneal tutulum gösteren TBC olgularında ise incelemeye asit örneklemesi ile başlanmalı, serum asit albümin gradienti (SAAG), hücre sayımı, tiplendirmesi, asit adenozin deaminaz (ADA) ölçümleri yapılmalıdır.

\section{KAYNAKLAR}

1. Raviglione MC, Snider DE Jr, Kochi A. Global epidemiology of tuberculosis: morbidity and mortality of a worldwide epidemic. JAMA 1995; 273:220-6.

2. World Health Organization. Global Tuberculosis Control 2011. Available at: http://www.who.int/tb/publications/global_report/201l/gtbrl1 _full.pdf

3. Braun MM, Byers RH, Heyward WL, et al. Acquired immunodeficiency syndrome and extra-pulmonary tuberculosis in the United States. Arch Intern Med 1990;150:1913-6.

4. Ihekwaba FN. Abdominal tuberculosis: a study of 881 cases. J R Coll Surg Edinb 1993;38:293-5.

5. Talwar BS, Talwar R, Chowdhary B, Prasad P. Abdominal tuberculosis in children: an Indian experience. J Trop Pediatr 2000;46:368-70.

6. Pulimood AB, Amarapurkar DN, Ghoshal U,et al. Differentiation of Crohn's disease from intestinal tuberculosis in India in 2010. World J Gastroenterol 2011;17:433-43.
Peritoneal TBC'de tipik olarak SAAG $<1,1$, dominant hücre lenfosit ve asit ADA >30 U/L'dir (10-11). Asitte ayrica basil yönünden boyama, PCR ve kültür de yapılması da önerilmektedir. Tanıya ulaşılamayan olgularda ultrasonografi veya tomografi ile periton biyopsisi yapılması düşünülmelidir. Benzer biçimde nodal TBC'den şüphe edilen olgularda da tomografi ile biyopsi gündeme gelebilmektedir. Hala basili göstermek mümkün olmamışsa laparoskopik inceleme kaçınılmazdır. İleus/subileus ile başvuran olgularda da laparotomi daha ön planda tutulması gereken bir seçenektir.

Basili göstermeye yönelik metodların farklı duyarlık ve özgüllükleri nedeniyle metodların kombine kullanımı önerilmektedir. Doku kültürü duyarlığı \%21-55 arasında değişmekte, ancak özgüllüğü \%100 olan bir inceleme olup, sonuca 3 ile 8 hafta arasında ulaşılabilmektedir $(13,14)$. PCR duyarlılığ \%30-88 arasında ve özgüllüğü \%100'e ulaşmaktadır $(15,16)$. Histopatolojik incelemenin duyarlığı \%30-40 arasında değişmektedir $(12,13)$.

Klasik tedavi seçeneği dörtlü anti-TBC ilaçların kullanılmasıdır. Farklı yayınlarda farklı tedavi süreleri bildirilse de tedavinin en az 9 ay olması konusunda çoğu yazar ortak görüştedir (2,7-10). Gecikmiş tedavinin mortaliteyi arttırdığı ve hastanın durumunu ağırlaştırdığı da bilinen bir gerçektir. Serilere bakllacak olursa mortalitenin \%20'ler civarında olduğu ve bu oranın siroz hastalarında daha da yükseldiği saptanmaktadır $(17,18)$. Mortalite daha çok postoperatif olarak görülmekte ve altta yatan malnütrisyona, perforasyona veya sepsise bağlanmaktadır.

Abdominal TBC tipik olmayan semptomatolojisi, basili göstermenin güçlügü ve diagnostik metodların farklı sensitiviteleri nedeniyle tanı konması güçlük arz eden bir hastalıktır. Tanı konabilmesi için öncelikle şüphelenmek, hastanın özgeçmişini ve aile öyküsünü daha ayrıntılı sorgulamak ve tanı yöntemlerinin birkaçını ard arda kullanmak gerekebilmektedir.

7. Chou CH, Ho MW, Ho CM, et al. Abdominal tuberculosis in adult: 10year experience in a teaching hospital in central Taiwan. J Microbiol Immunol Infect 2010;43:395-400.

8. Khan R, Abid S, Jafri W, et al. Diagnostic dilemma of abdominal tuberculosis in non-HIV patients: an ongoing challenge for physicians. World J Gastroenterol 2006;12:6371-5.

9. Bölükbaş C, Bölükbaş FF, Kendir T, et al. Clinical presentation of abdominal tuberculosis in HIV seronegative adults. BMC Gastroenterol 2005;5:21.

10. Sanai FM, Bzeizi KI. Systematic review: tuberculous peritonitis--presenting features, diagnostic strategies and treatment. Aliment Pharmacol Ther 2005;22:685-700.

11. Dulger C, Adali E, Avcu S, Kurdoglu Z. Large mesenteric cyst mimicking tuberculous ascites. Case Report Med. 2010;2010:725050. doi: $10.1155 / 2010 / 725050$. 
12. Yönal $\mathrm{O}$, Hamzaoğlu HO. What is the most accurate method for the diagnosis of intestinal tuberculosis? Turk J Gastroenterol 2010;21:91-6.

13. Pulimood AB, Ramakrishna BS, Kurian G, et al. Endoscopic mucosal biopsies are useful in distinguishing granulomatous colitis due to Crohn's disease from tuberculosis. Gut 1999;45:537-41.

14. Amarapurkar DN, Patel ND, Rane PS. Diagnosis of Crohn's disease in India where tuberculosis is widely prevalent. World J Gastroenterol 2008;14:741-6.

15. Leung VK, Law ST, Lam CW, et al. Intestinal tuberculosis in a regional hospital in Hong Kong: a 10-year experience. Hong Kong Med J 2006;12:264-71.
16. Gan H, Ouyang Q, Bu H, et al. Value of polymerase chain reaction assay in diagnosis of intestinal tuberculosis and differentiation from Crohn's disease. Chin Med J (Engl) 1995;108:215-20.

17. Chow KM, Chow VCY, Szeto CC. Indication for peritoneal biopsy in tuberculous peritonitis. Am J Surg 2003;185:567-73.

18. Chow KM, Chow VCY, Hung LCT, et al. Tuberculous peritonitis-associated mortality is high among patients waiting for the results of mycobacterial culture of ascitic fluid samples. Clin Infect Dis 2002;35:409-13. 